\title{
Regulatory Report
}

National Cancer Institute

\section{Source}

National Cancer Institute. Regulatory Report. NCI Thesaurus. Code C97107.

A type of report required by a regulatory agency. 